\title{
THE INFLUENCE OF FRENCH ON AFRIKAANS MILITARY TERMS
}

Cdr G. Nonin*

\begin{abstract}
Die invloed van Frans op die Afrikaanse militêre taal kan teruggevoer word tot die sestiende eeu. Baie Franse soldate was Hugenote en veterane van godsdienstige oorloë wat in Nederland geveg het en heelwat militêre terme in die Nederlandse taal gevestig het. Vanaf 1652 tot die herroeping van die Edik van Nantes in 1685, het sommige van hulle afstammelinge en nuwe Hugenote-immigrante hulle in Suid-Afrika gevestig. Die Hugenote se bydrae tot ons militêre geskiedenis is egter nie tot die linguistiek beperk nie. Baie Hugenootsoldate het uitgeblink op die slagveld tydens die oorloë van die Groot Trek en in die wetenskap van militêre argitektuur. Kontemporêre Franse invloed op die Afrikaanse militêre taal, alhoewel in 'n groot mate 'n realiteit, blyk ' $n$ oorgangstadium te wees vanweë die gevorderde stadium van die ontwikkeling van Afrikaans.
\end{abstract}

The influence of French on the Afrikaans military language is most pervasive. Investigation of this phenomenon takes us on a fascinating journey through time and space, right back to the Middle Ages in the Netherlands. There, the influence of French was already strongly felt at cultural, commercial and political levels, through the strong links with France. For many centuries, French was the second language at court and in educated circles, a situation favourable for the military linguistic osmosis which was to occur in the troubled times of the 16 th and 17 th centuries. A dramatic, if episodic, illustration of the use of French is provided by the last words of William of Orange when he was murdered in 1584: According to contemporary reports, he exclaimed in French: 'Mon Dieu, aie pitié de mon âme, et de ton pauvre peuple'.

From their Italian campaigns, the French had brought back new notions of warfare which, in Italy, had by then become a science and many books were then written in, and translated into French. At the same time, a technical revolution occurred in the field of warfare, namely the advent of the fire-arm. This resulted in a multitude of specializations among soldiers, and in drastic revisions of strategy and tactics. On the linguistic plane, an alarming number of neologisms (Italian, French and German) appeared, often referring to the same device, eg bombardes, basilics, passe-volans, arquebuzes.

The French soldier made a significant appearance in the Netherlands after the religious wars. It appears that, at that time, France was experiencing the 'Veteran Syndrome', a syndrome, which contrary to contemporary American belief, apparently did not originate during the Vietnam
War. The French government was faced with a generation of veterans who, even in those relatively uncomplicated times, could not adjust to civilian life. The war in Flanders offered an ideal opportunity to 'relocate' those veterans, particularly the Huguenots whose sympathies were understandably with the Prince of Orange. The contribution of French manpower to the Flanders theatre of war was very much appreciated there because of their bravery despite certain Gallic traits, such as fickleness and rashness, which were so feelingly documented by Julius Caesar in De Bello Gallico.

In those times, war was conducted mainly with mercenary armies and the armies fighting in the Netherlands consisted of soldiers of many nationalities (English, French, German, Swiss inter alia) and this created an international background favourable to the assimilation of new military terms. The greatest influence was exerted by the French and the Germans, but mostly by the French. Although many of the terms used by the French had their roots in the Italian tongue one must remember that by that time, they had been fully integrated into the French military terminology, this mostly through the widely-read translations of the great military works of Mendoza, Ufano and others.

Two interesting observations arise in this context. Firstly, it appears that English contributed little, if anything to the vocabulary explosion in the Netherlands. This is in sharp contrast to the modern tendency there. Secondly, it is interesting to note that the German military contingent in many ways helped to promote French terminology through their acceptance of many terms in preference of their own: Kanone, quartier, leute- 
nant, munition, marschieren, etc. Many of these words are to be founds in Afrikaans today, albeit in modified form.

Towards the beginning of the 17 th century, when modern Dutch started evolving, certain French words displayed hitherto well established terms; for example, Capitaine replaced Hopman.

These linguistic integrations and changes, however, did have their opponents: Purists such as Kilaen and Simon Stevin virulently denounced the introduction of such gallicisms. But they were strongly opposed by the military who cared little for purity of language and whose main concern was that words (of whatever etymology or morphology) should result in action. The purists, thus, were caught in the eternal struggle of customary usage (abusage?) versus correct (pedantic?) terminology, and they lost.

Let us now review some of the French words adopted during that period, together with the forms which they assumed first in Dutch and then later in Afrikaans:

\begin{tabular}{|c|c|c|}
\hline FRENCH & DUTCH & AFRIKAANS \\
\hline Affust & affuyte & affuit \\
\hline alarme & $\begin{array}{l}\text { alarme } \\
\text { alarm } \\
\text { allarme }\end{array}$ & alarm \\
\hline amunition & $\begin{array}{l}\text { ammonicie } \\
\text { ammonitie } \\
\text { ammunitie } \\
\text { munitie }\end{array}$ & ammunisie \\
\hline artillerie & $\begin{array}{l}\text { artillerie } \\
\text { artillerye }\end{array}$ & artillerie \\
\hline bagage & $\begin{array}{l}\text { bagagie } \\
\text { baggagie }\end{array}$ & bagasie \\
\hline bastion & bastion & bastion \\
\hline bataillon & bataillon & bataljon \\
\hline batterie & $\begin{array}{l}\text { batterie } \\
\text { batterye }\end{array}$ & battery \\
\hline calibre & caliber & kaliber \\
\hline canon & $\begin{array}{l}\text { canon } \\
\text { kanon }\end{array}$ & kanon \\
\hline canonier & $\begin{array}{l}\text { canonnier } \\
\text { kanonier }\end{array}$ & kanonnier \\
\hline capitaine & capiteyn & kaptein \\
\hline cartouche & kerdous & kardoes \\
\hline colonel & $\begin{array}{l}\text { colonel } \\
\text { kolonnel }\end{array}$ & kolonel \\
\hline
\end{tabular}

commandeur commandeur kommandeur In Afrikaans, this was later used as a naval rank, probably owing to English influence. Originally, the term applied to an officer of flag rank: Van Riebeeck was a "Commandeur"

\begin{tabular}{|c|c|c|c|}
\hline fort & fort & fort & \\
\hline garnison & $\begin{array}{l}\text { garnisoen } \\
\text { garnison }\end{array}$ & garnisoen & \\
\hline general & generael & generaal & \\
\hline grenade & $\begin{array}{l}\text { granade } \\
\text { granate }\end{array}$ & granaat & \\
\hline infanterie & $\begin{array}{l}\text { infanterie } \\
\text { infanterije }\end{array}$ & infanterie & \\
\hline lieutenant & lieutenant & luitenant & \\
\hline magasin & $\begin{array}{l}\text { magasijn } \\
\text { magazijn }\end{array}$ & magasyn & \\
\hline $\begin{array}{l}\text { marcher } \\
\text { militaire }\end{array}$ & $\begin{array}{l}\text { marcheren } \\
\text { militaire }\end{array}$ & $\begin{array}{l}\text { marsjeer } \\
\text { militêr }\end{array}$ & \\
\hline mine & mine & myn & $\begin{array}{l}\text { Applies now to } \\
\text { the explosive de- } \\
\text { vice rather than } \\
\text { to the tunnels } \\
\text { dug to place it. }\end{array}$ \\
\hline mortier & mortier & mortier & \\
\hline $\begin{array}{l}\text { mousquet } \\
\text { mutiner }\end{array}$ & $\begin{array}{l}\text { musquet } \\
\text { muytineren } \\
\text { muyten }\end{array}$ & $\begin{array}{l}\text { musket } \\
\text { muit }\end{array}$ & \\
\hline officier & officier & offisier & \\
\hline ordre & ordre & orde & $\begin{array}{l}\text { Only in the sense } \\
\text { of disposition. }\end{array}$ \\
\hline pionnier & pionier & pionier & $\begin{array}{l}\text { Used now to des- } \\
\text { ignate a person } \\
\text { who exercises } \\
\text { entry control for a } \\
\text { military establish- } \\
\text { ment, it original- } \\
\text { ly referred to a } \\
\text { workman em- } \\
\text { ployed by the } \\
\text { army to do man- } \\
\text { ual labour. }\end{array}$ \\
\hline pont & ponte & pont & \\
\hline prevot & $\begin{array}{l}\text { prevoost } \\
\text { provoost }\end{array}$ & provoos & \\
\hline quartier & quartier & kwartier & \\
\hline ronde & ronde & rondte & \\
\hline salve & salvo & salvo & \\
\hline $\begin{array}{l}\text { soldat } \\
\text { trousse }\end{array}$ & $\begin{array}{l}\text { soldaet } \\
\text { tros }\end{array}$ & $\begin{array}{l}\text { soldaat } \\
\text { tros }\end{array}$ & \\
\hline
\end{tabular}

It is also to be noted that many of these terms appear, in their Dutch form, in the diaries of Jan van Riebeeck.

This linguistic contribution was by no means the only one by the French to our fair land, as the following brief historical survey will strive to show.

The revoking of the Edict of Nantes on the 22nd October 1685 was a milestone in the history of South Africa, for it marked the beginning of the great Huguenot exodus from France. It is estimated that between 250000 and 300000 protestants left France between 1685 and 1700; out of these, according to Louvois, 100000 had received military training. A measure of the calibre of these immigrants and of their acceptance by host countries (in particular South Africa) is given by H.V. Morton in his book In search of South Africa (London, 1948): 
"Among all the religious and political refugees who at one time or another left their land, the Huguenots alone appear to have been welcomed everywhere and to have given their skill and their loyalty unquestioningly to the country of their adoption."

Morton continues with the following statement:

"Their arrival at the Cape was one of the fortunate moments in South African history. There were only about two hundred of them, but they have influenced South Africa out of all proportion to their numbers."

We must keep in mind, however, that one must go back to 1652 since among others Jan van Riebeeck and Cornelis van Quaelberg had French wives. Although the Huguenots who arrived at the Cape with the "Voorschoten" and the "Oosterland" numbered only a few soldiers, they were to make a significant contribution to our country's military history. At a parade held at Stellenbosch on 19 October 1688, new French immigrants were already found among the 200 soldiers assembled there. In 1695, the burghers of Drakenstein formed an infantry company under Huguenot leader Jacques de Savoye and by 1706, all three officers of the Drakenstein burgher infantry were Huguenots - Abraham de Villiers, Jan Durand and Phillipe des Pres.

Of particular interest in those early days, is the fact that the first burgher commando consisting entirely of volunteers was raised at the instigation of a Huguenot woman, Geertrug du Toit who was the second wife of Pierre Rousseau.

Cape governor Mauritz de Chavonnes (1714-1724) was in essence a Huguenot, tracing his ancestry to Gaspard de Coligny and William the Silent, Prince of Orange. His brother, Dominique Pasques de Chavonnes, was the first Frenchman to hold the post of Commander of the Cape Garrison (1686-1689) and his son followed in his footsteps as Commander of the same garrison in 1714 .

From the beginning of the 18th century, a system of temporary and permanent batteries of French design were erected: one of these was the Chavonnes (or Great) Battery which was situated at the foot of Signal Hill.

In 1781, Pierre André de Suffren, in command of seven ships, prevented the British invasion and immediately afterwards, began consolidating the defence of the Cape with the help of Brigadier Count de Conway. A retrenchment, called the French Line was built between Fort De Knokke and Devil's Peak, the West Fort was extended, the "French Fort" was built at Constantia Nek and the "Dutch Line" was designed by a brigade of French Engineers.

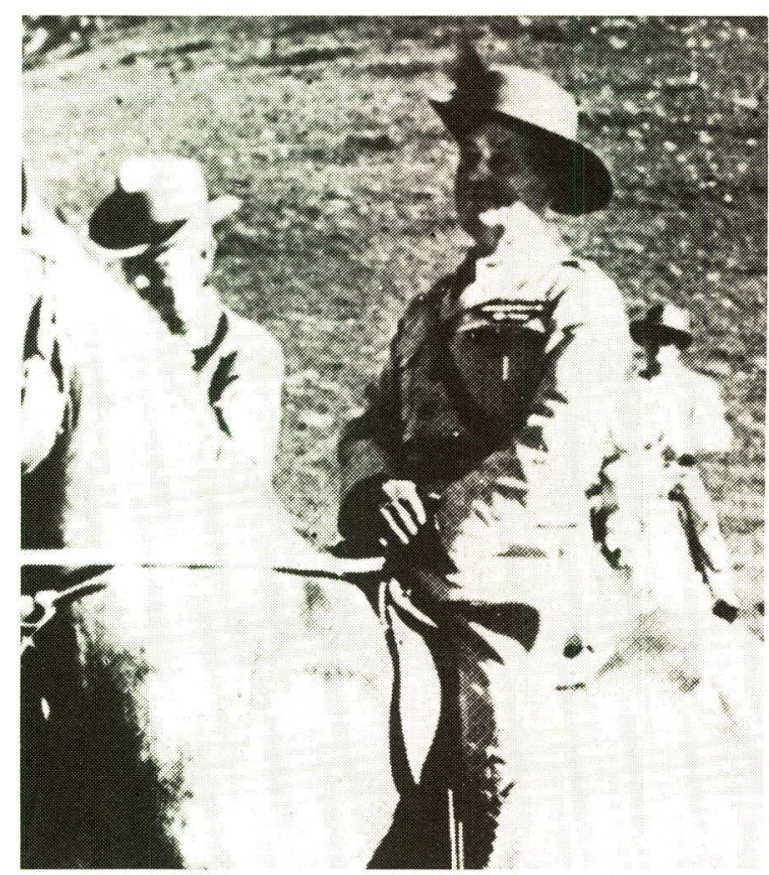

Col Robert de Kersauson, a Frenchman who fought with General De Wet in the Anglo-Boer War.

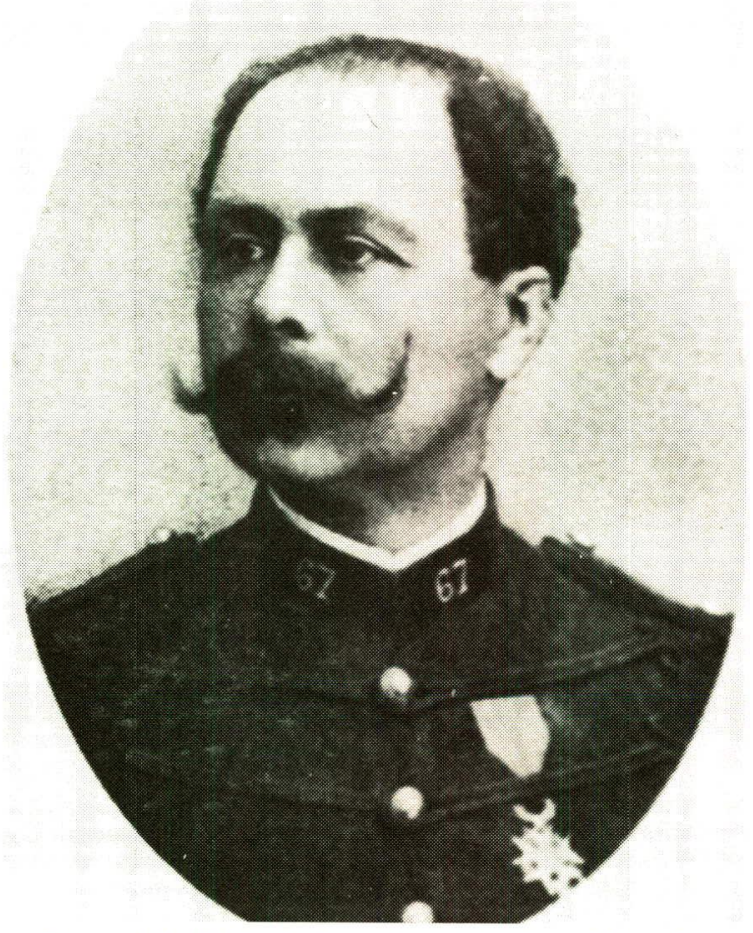

General De Villebois Mareuill, a French soldier who fought in the Anglo-Boer War and was appointed combat general (veggeneraal) 
During the 19th Century, famous French names made their mark on the history of our country: F.S.V. le Sueur who fought the British in 1806, Piet Retief, who in 1837 was elected governor of all the Voortrekkers, Jacobus Nicolaas Boshoff who as President of the Orange Free State, laid the foundation for that State's Defence Force.

After the Jameson raid in 1896, L. Grunberg, a former French artillery officer, conceived the idea to build forts around Pretoria, in a design similar to the Maginot Line. Although his design was rejected, the contract for the construction of the accepted design was granted to Schneider and Co of Le Creusot France who handed over the line to the Transvaal Government in 1898.

So much for the past: what about the present? Twenty years ago, the South African Defence Force purchased submarines from France. Our submariners were taught basic French and sent to France for training. This training was supplied uniquely in French, with the result that, three years later, there appeared in the Defence Force a breed of sailors trained to give and receive orders in French, to read French documentation and who knew every part of their boat intimately, but mostly by its French term. Although most of the documentation has now been translated and several generations of captains and crews have come and gone, there remains linguistic vestiges of those times. Indeed the Navy is not the only arm of the Service which has been thus affected: The South African Air Force, through the acquisition of French aircraft, has also inherited terms such as: aileron, canard, souris, point fixe and boule.

These tems have been tolerated, if not accepted, up to now. Are we to infer that we have entered another period of French influence on the Afrikaans military language? Will those recently important terms finally servive to obtain our seal of approval? I personally doubt it for, in contrast with the nascent and vulnerable Dutch of yore, the Afrikaans military language is sophisticated, well-established and in a position to deal with any military and technological innovation. Besides, the Afrikaans-speaking South African soldier today is intelligent, an expert in his field and above all, conscious of his linguistic heritage. He thus tends to resist indiscriminate borrowing at the expense of a purity of language which is perfetly attainable in his mother-tongue.

It seems, thus, as though we can regard the influence of French on the Afrikaans military language as a purely historical event which, through the Dutch and Huguenot settlers, contributed significantly if not vitally to the military foundations of the Afrikaans language. For this contribution, we of the South African Defence Force, on this, the tricentennary of the advent of the French Huguenots, pay homage to those intrepid settlers.

${ }^{*}$ Cdr. G. Nonin is S01 Terminology at the SADF Language Service and in charge of Computerised Terminology Systems.

\section{Bibliography}

Böeseken, A.J. Simon van der Stel en sy Kinders.

Boucher, M. French Speakers of the Cape; the European Background.

Christol, Frederic, 1850-1933. Fils de héros. Paris: Fischbacher, 1921.

Pama, C. Die Groot Afrikaanse Familienaamboek.

Schulten, Cornelis, Marais. Contribution à l'étude des termes militaires français en néerlandais 1567-1625. Proefschrift ter verkrijging van de graad van doctor in de letteren, 1966.

Van der Waag, J. The Military Participation of the French Huguenots (SAW Argief).

Dictionary of South African Biography. 